\title{
HOW THE INTEGRATED YOGA PRACTICE IMPACTS THE VISUAL PROCESSING OF SPECIALLY ABLED CHILDREN?
}

KEY WORDS: Yoga, pranayama, meditation, mental retardation, cognitive

\section{Merin \\ Chandanathil}

\section{Kunal*}

\section{Kishan Kadur}

Assistant Professor, Dept. of Pathophysiology, American University of Antigua, College of Medicine, Antigua,WI.

Associate Professor, Dept. of Physiology, Kasturba Medical College, Mangalore, Manipal Academy of Higher Education, Manipal, Karnataka, India. *Corresponding Author

Associate Professor, Dept. of Pathophysiology, American University of Antigua, College of Medicine, Antigua,WI.

Background and objectives: To investigate if integrated yoga practice affect the Visuo-spatial Cognition of Specially Abled Children.

Material and method: Eighty clinically diagnosed mentally challenged persons aged between 12 - 25 years were randomly allotted to control and study groups. Study group practiced Pranayama (Nadishodhan and Kapalbhati), Aum chanting and Meditation for 30 minutes daily, 6 days in a week for 3 weeks. Control group carried on with their normal school routine.Visual Processing was studied for a) Visual- Spatial Relation b) Picture Recognition and c) Planning. The parameters were measured twice, once before the starting of the intervention and later at the end of follow-up period. Results: Both the groups were comparable in their baseline scores. At follow-up, scores of the visual-spatial relation and picture recognition showed significant improvements in both the groups, but, the change in the scores of planning was significant only in study group. However, the improvement in all three categories were significantly higher in the study group as compared to the control group.

Interpretation and Conclusion: This study demonstrates the beneficial influences of pranayama and meditation on Visual Processing, suggests that pranayama and meditation improves the performance of prefrontal lobe and other cortical and subcortical areas and their neuronal connection involved in this process.

It may further contribute in improvement of overall intelligence of mentally retarded persons.

\section{INTRODUCTION}

Ranging from the overtly positive French expression "les infants du born Dieu" (God's children) to the exclamation of Martin Luther "the devil sits where their souls should be", the mental retardation (MR) has long been of interest to the academicians and researchers alike. Seguin, a French educator was pioneer in starting the "special training" to the "special" children ${ }^{1}$

' $A U M$ ' chanting is shown to decreased physiological alertness with better synchronised and improved sensory sensitivity ${ }^{2}$. It deactivates thalami, hippocampus, orbito-frontal, anterior cingulate, and parahippocampal gyrus ${ }^{3}$. Nadishodhana is reported to improve higher mental functions, and cardiorespiratory performance ${ }^{4}$. It causes contralateral hemisphere dominance; where left nostril breathing improves spatial skills while right nostril breathing improves verbal skills ${ }^{5-7}$. Decarboxylation and oxygenation was improved by Kapalbhati which keeps the respiratory centres quiet but stimulates the other nerves ${ }^{8}$. Meditation helps the people with psychiatric disorders and specific disabilities ${ }^{9}$. Yoga is known to improve the concentration in disable children and decrease the problems of Attention Deficit/Hyperactivity Disorder and other behavioural problems ${ }^{10}$. Frontal lobe functions, academic achievement, self-confidence, intelligent quotient, emotional stability, and social adaptation were improved by meditation practice in special children ${ }^{11-13}$.

\section{MATERIALS AND METHODS}

This prospective case-control study involved mentally challenged children attending a Special School, in Mangalore, Karnataka, India. Institutional ethical committee approval and written approval and consent of the principal of this special school were obtained.

\section{STUDY SUBJECTS:}

80 subjects aged between 12 to 25 years were randomly and equally allotted to the control and the study group.

\section{EXCLUSION CRITERIA:}

Persons suffering with severe mental retardation, cerebral www.worldwidejournals.com palsy, severe sensory deficit, severe hyperkinetic syndrome, and physically handicapped, as they were expected not able to follow the instructions.

\section{INTERVENTION:}

As per the descriptions of the book "Hatha Yoga Pradipika", study group was trained for Nadishodhan Pranayama, Kapalbhati, 'AUM' chanting and meditation and practiced under the supervision of investigator and school teachers for 30 minutes daily during 9 AM to 9.30 AM, 6 days in a week excluding Sunday, for 3 weeks ${ }^{14}$.

Control group subjects were matched for chronological age, sex, waist-hip ratio, BMI, and environmental background to that of the study group. They did not participate in yogic practice; instead, carried on with their normal school routine.

Visual Processing Tests was evaluated for three categories, namely a) Visual- Spatial Relation b) Picture Recognition and c) Planning, according to the guidelines provided by Woodcock-Johnson III Tests of Cognitive Abilities (WJ III COG) $)^{15}$.

a. Visual- Spatial Relation: Subjects were asked to identify the two or more pieces that form a complete target shape.

b. Picture Recognition: Subjects were asked to identify a subset of previously presented pictures within a field of distracting pictures.

c. Planning: Subjects were to trace a pattern without removing the pencil from the paper or were asked to copy given geometrical shapes.

Data Analysis: The obtained data was analysed using SPSS version 7.5. Unpaired-t test was applied to unpaired data of independent observations made in two separate groups. Paired $t$ test was applied to paired data of independent observations from one sample only. T-values and p-values were compared. Statistical significance was taken to be a $p$ value of less than 0.05 . 


\section{RESULTS}

Out of 80 subjects, all 40 in the study group and 36 in the control group were available for follow-up. Therefore the data of only 76 subjects was analysed.

The baseline mean score of subcategory of verbal comprehension namely, picture vocabulary, verbal analogies and general information were comparable between the groups, as shown in Table 1.

\begin{tabular}{|c|c|c|c|c|}
\hline \multicolumn{5}{|c|}{$\begin{array}{c}\text { Table l - Comparison of baseline score of each } \\
\text { categories of visual processing between the study and } \\
\text { control groups }\end{array}$} \\
\hline Parameters & $\begin{array}{c}\text { Control } \\
\text { group }\end{array}$ & Study group & $\begin{array}{c}\text { t- } \\
\text { value }\end{array}$ & $\begin{array}{c}\text { p- } \\
\text { value }\end{array}$ \\
\cline { 2 - 5 }$($ Mean \pm SD) & (Mean \pm SD) & & \\
\hline $\begin{array}{c}\text { Visual- Spatial } \\
\text { Relation }\end{array}$ & $5.11 \pm 1.94$ & $5.20 \pm 1.76$ & 0.21 & $0.83 \mathrm{~ns}$ \\
\hline Picture Recognition & $3.39 \pm 2.05$ & $3.35 \pm 1.54$ & 0.094 & $0.92 \mathrm{~ns}$ \\
\hline Planning & $4.67 \pm 3.10$ & $5.02 \pm 2.76$ & 0.533 & $0.59 \mathrm{~ns}$ \\
\hline
\end{tabular}

$* *$ highly significant $-\mathrm{p}$ value $\leq 0.005 ; *$ significant $-\mathrm{p}$ value $\leq$ 0.05 ; non-significant (ns) - $p$ value $\geq 0.05$

At follow-up, scores of the visual- spatial relation and picture recognition showed significant improvements in both the groups, but, the change in the scores of planning was significant only in study group, as shown in Table 2.

\begin{tabular}{|c|c|c|c|c|c|}
\hline $\begin{array}{l}\text { Study } \\
\text { Group }\end{array}$ & Baseline & Follow-up & $\begin{array}{c}\text { Mean } \\
\text { difference }\end{array}$ & $\begin{array}{c}\mathrm{t} \\
\text { value }\end{array}$ & $\begin{array}{c}\mathrm{p} \\
\text {-value }\end{array}$ \\
\hline $\begin{array}{c}\text { Visual- } \\
\text { Spatial } \\
\text { Relation }\end{array}$ & $\begin{array}{c}5.20 \pm \\
1.76\end{array}$ & $\begin{array}{c}8.10 \pm \\
1.82\end{array}$ & $2.90 \pm 1.88$ & 9.765 & $<0.001 * *$ \\
\hline \begin{tabular}{|c|} 
Picture \\
Recognition \\
\end{tabular} & $\begin{array}{c}3.35 \pm \\
1.54 \\
\end{array}$ & $\begin{array}{c}5.75 \pm \\
1.17 \\
\end{array}$ & $2.40 \pm 1.41$ & 10.761 & $<0.001 * *$ \\
\hline Planning & $\begin{array}{l}5.02 \pm \\
2.76 \\
\end{array}$ & $\begin{array}{c}6.32 \pm \\
2.61 \\
\end{array}$ & $1.30 \pm 1.83$ & 4.496 & $<0.001 * *$ \\
\hline $\begin{array}{c}\text { Control } \\
\text { Group }\end{array}$ & Baseline & Follow-up & $\begin{array}{c}\text { Mean } \\
\text { difference }\end{array}$ & $t$ value & p-value \\
\hline $\begin{array}{c}\text { Visual- } \\
\text { Spatial } \\
\text { Relation }\end{array}$ & $\begin{array}{l}5.11 \pm \\
1.94\end{array}$ & $\begin{array}{c}6.44 \pm \\
2.23\end{array}$ & $1.33 \pm 1.64$ & 4.882 & $<0.001 * *$ \\
\hline \begin{tabular}{|c|} 
Picture \\
Recognition
\end{tabular} & \begin{tabular}{|c}
$3.39 \pm$ \\
2.05
\end{tabular} & $\begin{array}{c}4.41 \pm \\
1.61\end{array}$ & $1.03 \pm 1.32$ & 4.672 & $<0.001 * *$ \\
\hline Planning & $\begin{array}{c}4.67 \pm \\
3.10\end{array}$ & $\begin{array}{c}4.75 \pm \\
3.23\end{array}$ & $0.08 \pm 1.05$ & 0.475 & $0.63 \mathrm{~ns}$ \\
\hline
\end{tabular}

$* *$ highly significant $-\mathrm{p}$ value $\leq 0.005$; significant $-\mathrm{p}$ value $\leq$ 0.05 ; non-significant (ns) - $p$ value $\geq 0.05$

The improvements in follow-up scores were significantly higher in study group as compared to the control group, as shown in Table 3 .

Table 3 - Comparison of follow up score of visual processing of study and control groups

\begin{tabular}{|c|c|c|c|c|}
\hline Parameters & $\begin{array}{c}\text { Control } \\
\text { group }\end{array}$ & $\begin{array}{c}\text { Study } \\
\text { group }\end{array}$ & $\begin{array}{c}\text { t- } \\
\text { value }\end{array}$ & p-value \\
\cline { 2 - 3 } & (Mean \pm SD) & (Mean \pm SD) & & \\
\hline $\begin{array}{c}\text { Visual- Spatial } \\
\text { Relation }\end{array}$ & $6.44 \pm 2.23$ & $8.10 \pm 1.82$ & 3.553 & $0.001 * *$ \\
\hline $\begin{array}{c}\text { Picture } \\
\text { Recognition }\end{array}$ & $4.41 \pm 1.61$ & $5.75 \pm 1.17$ & 4.157 & $<0.001 * *$ \\
\hline Planning & $4.75 \pm 3.23$ & $6.32 \pm 2.61$ & 2.343 & $0.022^{*}$ \\
\hline
\end{tabular}

**highly significant $-\mathrm{p}$ value $\leq 0.005$; *significant $-\mathrm{p}$ value $\leq$ 0.05 ; non-significant ( $\mathrm{ns}$ )-p value $\geq 0.05$

\section{DISCUSSION}

Yoga had been shown to positively influence the cognitive functions and the academic performances of both normal and mentally retarded population. The results of the present study are in agreement with the previous research works demonstrating the beneficial effects of pranayama and meditation on the cognitive functions, especially the verbal comprehension in mentally challenged population ${ }^{10,12,13}$.

Through the massive subcortical bundle of nerve fibers, the prefrontal cortex receives much pre-analyzed sensory information, especially on the spatial coordinates of the body that is necessary for planning the effective movements. Much of the output from the prefrontal area into the motor control system passes through the caudate portion of the basal ganglia-thalamic feedback circuit for motor planning. In the present study, tasks given under planning subcategory of visual processing required visual input and its analysis correct sequence and patterns of desired act for effective movement of fingers. The significant improvement observed in this skill suggests that pranayama and meditation improves the performance of prefrontal lobe and other cortical and subcortical areas and their neuronal connection involved in planning process ${ }^{16,17}$.

This study was carried out within the frame work of special school curriculum.

\section{Therefore this study is with certain limitations:}

1. Owing to the practical difficulties faced in handling and assessing mentally retarded children, all the subjects could not be assessed together. The time taken for CFT evaluation extended for 8 days. Therefore, only long lasting effects of yogic practice could be established.

2. This was a study on "Integrated Yoga" combining of pranayama, 'AUM' chanting and meditation. So, individual effect of each yogic practice couldn't be investigated.

3. This study did not evaluate the complete woodcock Johnson III cognitive function test battery.

4. The same set of task was repeated at baseline and at follow-up.

Further, research is needed to incorporate more numbers of subjects and to investigate the cognitive functions more thoroughly.

\section{CONCLUSION}

The practice of integrated yoga is beneficial in improving the cognitive functions of mentally challenged children. It has more effect on the ability of general information of verbal comprehension. The curriculum followed in this school also improves the cognitive functions though not to the extent of additional integrated yogic practice. The curriculum of special school should incorporate regular half an hour practice of integrated yoga.

Conflict of Interest: It was self-funded research work and none of the author has any financial and personal relationships with other people or organizations that could inappropriately influence (bias) our work.

\section{REFERENCES}

1. Kaplan \& Sadock. Mental Retardation. In: Comprehensive Textbook of Psychiatry. 7th Ed.New York:LippincottWilliams \&Wilkins; 2000.

2. Jella SA and Shannahoff-Khalsa DS. The effects of unilateral forced nostril breathing on cognitive performance. Int JNeurosci. 1993 Nov;73(1-2):61-8.

3. Kalyani BG, Venkatasubramanian G, Arasappa R, Rao NP, Kalmady SV, Behere RV, et al. Neurohemodynamic correlates of 'OM' chanting: A pilot functional magnetic resonance imaging study. International journal of yoga. 2011;4(1):3.Kumar S, Nagendra HR, Manjunath NK, Naveen KV, Telles S. Meditation on OM: Relevance from ancient texts and contemporary science. International journal of yoga. 2010 Jan 1;3(1):2.

4. Werntz, D., Bickford, R. G., Bloom, F. E. \& Shannahoff- Khalsa, D. Alternating cerebral hemispheric activity and the lateralization of autonomic nervous function, Hum Neurobiol. 1983;2(1):39-43.

5. Werntz, D., Bickford, R.G., \& Shannahoff-Khalsa, D. Selective hemispheric stimulation by unilateral forced nostril breathing, Hum Neurobiol. 1987;6(3):165-71.

6. Subbalakshmi NK, Saxena SK, Urmimala, D'Souza Urban JA. Immediate effect of 'nadi-shodhana pranayama' on some selected parameters of cardiovascular, pulmonary, and higher functions of brain. Thai journal of physiological sciences.2005 Aug;18(2):10-16.

7. Desai B, Gharote M. Effect of Kapalabhati on blood urea, creatinine and 
tyrosine.Act Nerv Super (Praha) 1990;32(2): 95-108.

8. Shannahoff -Khalsa DS. An introduction to kundalini yoga meditation techniques that are specific for the treatment of psychiatric disorders. The Journal of Alternative and Complementary Medicine 2004;10(1):91-101.

9. Hopkins JT, \& Hopkins LJ. A study of yoga and concentration. Academic Therapy 1979;14(3):341-45.

10. Marjorie B. The effects of curriculum based yoga on children with attention Deficit/ hyperactivity disorder. Ohio: A Maser's Research Project Presented to The Faculty of the College of Education Ohio University;2009.

11. Kenny M. Integrated movement therapy:Yoga-based therapy as a viable and effective intervention for autism spectrum and related disorders. International Journal of Yoga Therapy 2002;12:71-79.

12. Shamsher S. A Study on Effects of Selected Yogic Practices on Physical and Psychological Variables of Deaf and Dumb Children. Haridwar, Uttaranchal: Thesis Submitted For The Degree of Doctor of Philosophy In The Department Of Human Consciousness And Yogic Science, Gurukul Kangri University; 2006.

13. Uma K, Nagendra HR, Nagarathna R, Vaidehi S. \& Seethalakshmi R. The integrated approach of yoga: A therapeutic tool for mentally retarded children: A one year controlled study.J Ment Defic Res 1989;33(5):415-21.

14. Muktibodhanda S. Chapter Two: Shatakarma and Pranayama, In: Hatha Yoga Pradipika,Yoga Publication Trust, Munger, Bihar,India; verse 7-9 and verse 35

15. Mather N. \& Woodcock RW.Woodcock-Johnson III Tests of Cognitive Abilities Examiner's Manual Standard and Extended Batteries. Itasca, IL:The Riverside Publishing Company;2001.

16. Guyton AC. The Nervous System: C. Motor and Integrative Neurophysiology: Cerebral Cortex, Intellectual Functions of the Brain, Learning and Memory, In: Text Book of Medical Physiology, 11th ed. Philadelphia: Elsaviour and Saunders; 2006.p.714-28.

17. Ganong WF. Central and Pheripheral Neurophysiology: Learning, Memory, Language \& Speech, In: Review of Medical Physiology, 23rd ed. New Delhi: The Mc Graw Hill companies, LANGE publication;2010. p. 289-96. 